\title{
Structure and Role of the Board of Directors according to the Company Law of Jordan: The Need for Revision
}

\begin{abstract}
Bashar H. Malkawi*

Corporate governance is developing rapidly in many countries across the world. In this article, the existing state of corporate governance in Jordan is examined. Jordan does not have a corporate governance code per se. The article reveals that overall Jordan has in place some of the features of corporate governance best practice, but that there remains further progress to be made in areas such as independence of directors, compensation, and correlation between shareholding and entitlement to seats on the board. The article recommends legal reforms in order to enhance corporate governance in Jordan.
\end{abstract}

Keywords: corporate governance, Jordan, board of directors, compensation, board independence.

\section{Introduction}

The generally accepted definition of the phrase "corporate governance" comes from the seminal Report of the Committee on the Financial Aspects of Corporate Governance (the Cadbury Report). ${ }^{1}$ The Cadbury Report defines corporate governance as the system by which companies are directed and controlled. ${ }^{2}$ In other words, corporate governance is about the governance of corporations. At its most basic, corporate governance deals with

\footnotetext{
* Bashar H. Malkawi is Dean and Professor of Law at University of Sharjah, UAE. He holds an S.J.D in law from the American University, Washington College of Law, and an L.L.M in International Trade law from the University of Arizona.

${ }^{1}$ The Committee on the Financial Aspects of Corporate Governance was chaired by Sir Adrian Cadbury. The Cadbury Committee may be considered the mother of all corporate governance committees. The Cadbury Committee reported on corporate governance practices, primarily on the control and reporting functions of boards and the role of auditors. See Report of the Committee on the Financial Aspects of Corporate Governance (Dec. 1, 1992), available at <www.worldbank.org/html/fpd /private sector /cg/docs/cadbury.pdf (last visited March 1, 2018).

${ }^{2}$ Id. at. 2.5
} 
the relationships among the board, management and investors with respect to the control of corporations.

The development of corporate governance standards was influenced and fostered by globalization. ${ }^{3}$ Globalization has had a long history of affecting the development of the corporation. For example, the development of chartered companies in the sixteenth and seventeenth centuries arose out of increased trade. ${ }^{4}$

Corporate governance issues can be viewed as a trade-like issue. Trade increases competition, which has the effect of breaking down local barriers resulting in increased competition in the products market. Open competition directly affects the performance of a country's firms, raising the issue of whether a particular corporate governance model is a factor in a firm's performance. In addition, competition for capital means that corporations seeking capital need to provide good governance practices. ${ }^{5}$ Indeed, investors demand good governance practices as a condition of investment. ${ }^{6}$ Therefore, higher corporate governance standards in Jordan may provide a means of enhancing its competitiveness.

While the U.S. had its headline-grabbing corporate scandals involving companies such as Enron and World Com, ${ }^{7}$ Jordan also experienced its share of corporate troubles

\footnotetext{
${ }^{3}$ Globalization involves a stretching of economic activities across regions and marked by the intensification of interconnectedness and flows of trade, investment, finance, migration, culture. Moreover, globalization is speeding up global interactions and processes as the development of world-wide systems of transport and communication increases the velocity of the diffusion of ideas, goods, information, capital and people. See David Held \& Anthony McGrew, Globalization, Oxford Companion to Politics of the World 324 (Joel Krieger ed., 2001).

${ }^{4}$ See John Micklethwait \& Adrian Wooldridge, The Company: A Short History of a Revolutionary Idea 17-24 (2003).

${ }^{5}$ See generally Amir N. Licht, Cross-Listing and Corporate Governance: Bonding or Avoiding? 4 Chi. J. Int'l L. 141 (2003).

${ }^{6}$ See Governing the Modern Corporation, The Economist, May 5, 2001, at S30.

${ }^{7}$ See William J. Carney, The Costs of being Public after the Sarbanes-Oxley: The Irony of "Going Private", 55 Emory L.J. 141 (2006). See Laura Lin, The Effectiveness of Outside Directors as a Corporate Governance Mechanism: Theories and Evidence,, 90 Nw. U.L. Rev. 898 (2017).
} 
affecting not only large entities such as Petra Bank, ${ }^{8}$ but also some smaller companies. ${ }^{9}$ Over the years, there have been charges that companies hide information, have poor internal controls, and have negligent and incompetent boards of directors. In some instances there have been claims of fraud on the part of directors and auditors. ${ }^{10}$ All of which have underscored the need for higher corporate governance standards.

This paper will examine Jordan's current position on corporate governance of publicly-traded companies. The paper will comment on the role of the board of directors, conflicts of interest and related party transactions, liability of directors. This paper concludes with comments on the current status of corporate governance in Jordan and provides suggestions that might be considered as Jordan considers amendments to Companies Law or implementing regulations in order to improve corporate governance further.

\section{Background}

The origins of Jordan company law can be traced back to approximately 1929. The Jordanian Company Law of 1929 was modeled after British Companies Act. After World War II, French influence on Jordanian corporate law displaced the British influence. ${ }^{11}$ In the 1950s, partnerships were the dominant form of commercial enterprise. In 1964, with the promulgation of the Companies Law, a legal mechanism existed for the

\footnotetext{
${ }^{8}$ Petra Bank was Jordan's second bank. Due to poor corporate governance, Petra Bank collapsed and became one of the biggest corporate scandals in Jordan's history. See A Delicate State of Affairs, The Economist (Oct. 4, 2003). Another scandal involved IT company and the secret police where $\$ 1$ billion in loans went astray. This scandal became Jordan's largest scandals. See The Fall of a Kingmaker, The Economist (July 19, 2003).

${ }^{9}$ See M. Al-Basheer, The Non-Seriousness of the Regulatory Authorities Prevented Stopping Corruption and Failure of Companies, Al-Rai Newspaper (Apr. 21, 2001).

${ }^{10}$ Telephone Interview with a lawyer linked to corporate fraud cases in Jordan who asked for anonymity (August 21, 2006).

${ }^{11}$ See Thabet Koraytem, The Islamic Nature of the Saudi Regulations for Companies, 15.1 Arab L. Quarterly 63, 64 (2000).
} 
creation and operation of joint ventures, public shareholding companies, and limited liability companies. Twenty-five years after the Companies Law was promulgated a new law was enacted in 1989. The Companies Law of 1989 added new provisions related to formation, management, and liquidation of companies. The Companies Law of 1989 was further amended in 1997. The current Companies Law of 1997 includes provisions related to consolidation and foreign companies operating in Jordan. ${ }^{12}$

Following the establishment of the Amman Stock Exchange (ASE) in 1999, the government of Jordan encouraged local companies to expand and issue securities to the public. A large number of companies are family-owned with some public float or otherwise closely-held with a small minimum investor float. ${ }^{13}$ The owners of these companies had been reluctant to take their companies public for fear of diluting the controlling family's stake. The Companies Law offered protections to their ownership rights. A company could go public and be listed on the ASE while the founding shareholders maintained seventy-five percent of the shares. ${ }^{14}$ These policies provided incentives for the dispersal of corporate ownership, thus encouraging current controllers to maintain control at lower levels of ownership concentration. ${ }^{15}$

The publicly held corporations now play important role in the Jordanian economy. Publicly held corporations can be viewed in purely economic terms as a means by which capital is raised from a large number of public savers and used by businesses. There are

\footnotetext{
${ }^{12}$ See Companies Law No. 22 of 1997, Official Gazette No. 4202 (May 15, 1997), as amended by Provisional Companies Law No. 40 of 2002, Official Gazette No. 4533 (Feb. 17, 2002).

${ }^{13}$ See Jill Solomon \& Aris Solomon, Corporate Governance and Accountability 173 (West Sussex, England: John Wiley \& Sons Ltd 2005) (Jordan's system of corporate governance is insider-oriented with most companies being owned predominantly by founding families).

${ }^{14}$ See Companies Law No. 22 of 1997, Official Gazette No. 4202 (May 15, 1997), supra note 12, art. 99.

${ }^{15}$ Most of the world has concentrated ownership while the U.S. and UK have a widely dispersed ownership structure. The widely dispersed ownership structure usually relies more on market financing while the concentrated ownership structure looks more to private financing. See Rafael La Porta et al., Corporate Ownership around the World, 54 J. Fin. 471, 511-13 (1999).
} 
publicly traded corporations in which there is a control group. They range from traditional family owned businesses like the major banks (Arab Bank) to industrial companies (Kawther Investment and International Textile Manufacturing) where control remains in the original owners. The government of Jordan owned some companies. Institutional investors do not have great influence. However, the Social Security Corporation (pension fund) and Jordan Investment Corporation, in particular, hold a large percentage of shareholding.

There are ninety-eight companies, dominated by banks and insurance companies, listed on ASE. ${ }^{16}$ In 2017, market capitalization rose to a high of just over $\$ 14.2$ billion tempting new investors to enter the market to take advantage of the riches to be acquired through share ownership. ${ }^{17}$ In 2016 the market dropped precipitously and while stabilized, it has yet to regain its former highs. ${ }^{18}$ Some companies declared bankruptcy and were de-listed from ASE. There are many factors that contributed to the troubles in the capital market. These factors include easy credit for investors and questionable practices of company founders. A stronger system of corporate governance likely would have protected the market from some of the troubles. The Companies Law should be rewritten to assure adequate internal controls, provide greater protection for all stakeholders of a company, emphasizes the vital importance of the role of auditors, and promote independence of the board of directors and clarify its responsibilities.

\footnotetext{
${ }^{16}$ See Amman Exchange, Vol. XXV.1 Banks in Jordan Magazine 74 (Jan. 2017).

${ }^{17}$ See Amman Stock Exchange, Monthly Statistical Bulletin 36 (Sep. 2017).

${ }^{18}$ See Amman Stock Exchange, Jordan Times (June 4, 2017).
} 


\section{Inside Trading and Self-dealing}

The Companies Law of 1997 prevents and punishes insider trading. ${ }^{19}$ The chairmen of the board of directors, any member of the board of directors, general manager, and employees are prohibited from trading on the basis of insider information or to reveal it to others with the aim of manipulating the price. ${ }^{20}$ Any transaction based on insider information is considered void and the insider is liable for fines and damages. ${ }^{21}$

The Jordan Securities Commission (JSC) plays an important role in monitoring insider trading activities. The JSC monitors insider transaction electronically by matching transactions with its database of insiders. In 2004, the JSC discovered one violation of inside trading rules. ${ }^{22}$ However, the reaction to insider trading has not been as strong. Though insider trading has been considered a punishable criminal offense, prosecutions and punishments have occurred rarely, if ever. In fact, thus far, Jordan did not impose a penalty of imprisonment for such an offense. In Jordan, corporate insiders should face hefty fines and prison sentences for trading securities on the basis of inside information because such practices take unfair advantage of stockholders.

Related-party transactions such as transaction between directors, general manager, and the company are prohibited. ${ }^{23}$ For example, loans made to directors are prohibited.

\footnotetext{
${ }^{19}$ Insiders are those directors, officers and controlling shareholders who trade in their corporation's securities with an informational advantage secured through fiduciary relations with that particular corporation. See Ray J. Grzebielski, Friends, Family, Fiduciaries: Personal Relationships as a basis for Insider Trading Violations, 51 Cath. U.L. Rev. 467, 476 (2002).

${ }^{20}$ See Companies Law No. 22 of 1997, Official Gazette No. 4202 (May 15, 1997), supra note 12, art. 166.

${ }^{21} \mathrm{Id}$.

${ }^{22}$ In 2003, JSC found twenty-three violations of insider trading rules. See Jordan Securities Commission, Annual Report for 2004, table 3, available at <http://www.jsc.gov.jo/report/AnnualReport2004.pdf>. See also Jordan Securities Commission, Annual Report for 2003, table 1, available at $\langle$ http://www.jsc.gov.jo/report/AnnualReport2003.pdf $>$.

${ }^{23}$ See Companies Law No. 22 of 1997, Official Gazette No. 4202 (May 15, 1997), supra note 12, art. 148.
} 
The law requires disclosure by the company of loans made to related parties e.g. parent companies, subsidiaries, directors, employees, or the company or related companies. ${ }^{24}$ However, the definition of related-party transaction is unclear. ${ }^{25}$ Indeed, family members of directors are excluded from prohibition of related-party transaction. Moreover, relatedparty transactions should not be prohibited by law. Rather, the law should require adequate disclosure and approval processes. For example, the law could require that related-party transactions be approved by an issuer's audit committee or comparable body.

\section{Corporate Boards in Jordan}

\section{A. Size and Composition}

Companies in Jordan have single-tier boards. ${ }^{26}$ Boards consist of odd numbers of members with a minimum of three and maximum of thirteen. ${ }^{27}$ Shareholders who own minimum amount of shares as specified in the company's articles of association are given the opportunity to sit on the board of directors of the company, unless disqualified by virtue of being convicted of an offense involving moral turpitude. Representatives of the Jordanian government when the government is a shareholder can be eligible for membership in the board of directors. ${ }^{28}$ Corporate bodies represented by natural persons

\footnotetext{
${ }^{24} I d$. art. 139.

${ }^{25}$ Related party could be defined as one that can exercise control or significant influence over another party to the extent that one of the parties may be prevented from pursuing its own separate interests.

${ }^{26}$ Germany company model is a two-tier board of directors. One board actively manages the business and affairs of the company, while the other board, elected in part by shareholders and in part by labor, is responsible for the supervision of the management board. See Thomas J. Andre, Jr., Some Reflections on German Corporate Governance: A Glimpse at German Supervisory Boards, 70 Tul. L. Rev. 1819 (1996). See also J. Robert Brown, Jr., The Demythification of the Board of Directors, 52 Am. Bus. L.J. 131 (2015).

${ }^{27}$ See Companies Law No. 22 of 1997, Official Gazette No. 4202 (May 15, 1997), supra note 12, art. 132.a.

${ }^{28} I d$. art. 135 .
} 
may serve as directors thus raising the issue how to allocate liability. ${ }^{29}$ The Companies

Law of 1997 did clarify this issue. ${ }^{30}$

\section{B. Qualifications of Board of Directors}

In Jordan, the primary qualification for board membership according to the Companies Law of 1997 is share ownership. ${ }^{31}$ Besides ownership of a minimum number of shares, there are no other requirements for nomination for membership in the board of directors. For example, there are no qualification requirements such as minimum age (e.g. thirty years old), minimum years of experience (e.g. five years), or a demonstrated ability to contribute to the company. The Companies Law of 1997 does not provide great detail with respect to qualifications of boards of directors. The law does not require board members to meet at least one of the following characteristics: the ability to motivate people, contribute strategic insight, expertise in accounting and corporate finance, and the ability to perform during periods of crises.

Usually, the roles of the chief executive officer or general manager and chairman of Jordanian companies are combined. The board of directors and management are dominated by controlling families. ${ }^{32}$ Jordan should strive for more board independence by introducing the requirement that two non-shareholders for example must be included in a company's board of directors. To be considered independent, a board must consist of

\footnotetext{
${ }^{29} \mathrm{Id}$. art. 136.

${ }^{30}$ Liability can be attributed to natural person representing the corporate body or to corporate body alone. Criminal liability can pursued against the natural person while civil liability can be pursued against the corporate body. See Joel Seligman, A Modest Revolution in Corporate Governance, 80 Notre Dame L. Rev. 1159 (2005). See also Stephen M. Bainbridge and M. Todd Henderson, Boards-R-Us:

Reconceptualizing Corporate Boards, 66 Stan. L. Rev. 1051 (2014).

${ }^{31}$ See Companies Law No. 22 of 1997, Official Gazette No. 4202 (May 15, 1997), supra note 12, art. 133.a.

${ }^{32}$ See Globalization and Firm Competitiveness in the Middle East and North Africa Region 189-191 (Samiha Fawzy ed., 2002).
} 
a majority of non-executive directors and the roles of the general manager and chairman may not be combined. ${ }^{33}$

\section{Responsibilities of the Board of Directors}

The Jordanian Companies Law fails to state "duty of care" as the basic obligation of directors. However, the closest to a "duty of care" can be found in the Jordanian agency law. ${ }^{34}$ After all, the foundation of the duty of care lies in basic agency or trust law. A legal obligation like the duty of care is useful in because the corporate form involves a delegation of responsibility to those who manage property that they do not own. Thus, a director is expected to act as a prudent, diligent and active person would in similar circumstances (that is, as a corporate director would act), and that he cannot use lack of experience or knowledge as an excuse.

Throughout the 1970s and 1980s, it was common for company heads to hold many positions. Companies spun off subsidiaries, many of which continued to be family-held enterprises. Family-held enterprises designated relatives or other proxies to represent their interests on many boards. The number of cross- or interlocking boards meant that fertile ground existed for conflicts of interest. Now, Jordan Companies Law imposes upon managers and directors a duty of loyalty and regulates their conflicts of interest. A conflict of interest could arise from service on the boards of many companies, but this is addressed through the disclosure of the board members' other positions. As a general matter, the Jordanian Companies Law limits the number of comparable positions that an officer or director may occupy, although the limitations are not particularly restrictive.

\footnotetext{
${ }^{33}$ A "non-executive" director is one who is not a regular employee of the company and therefore does not oversee the routine functions of the company on a daily basis. See R.P. Austin, What is Corporate Governance? Precepts and Legal Principles, 3 NZ L. Rev. 335, 349 (2005).

${ }^{34}$ See The Jordanian Civil Code of Moslem Jurisprudence 128 (Hisham R. Hashem trans., 1990).
} 
No individual can be a member of more than five boards of directors of public shareholding companies in Jordan or a chairman of the board of more than three companies. ${ }^{35}$ However, the Companies Law should be amended to reduce the limit on the number of cross-board memberships from five to four or three and the number of crosschairmanships of boards of directors from three to two.

The Companies Law of 1997 sets forth the basic authority of the board of directors, which is, in essence, to perform all acts required for the management of the company and prepare the company's balance sheet and a profit and loss statement. ${ }^{36}$ The board adopts a system of proper internal controls to ensure compliance with applicable laws and regulations. ${ }^{37}$ The board of directors of a company must also prepare an annual report approved by the chairman of the board of directors and the general manager. ${ }^{38}$

The board selects the general manager and other key executives and specifies their roles, responsibilities and power. ${ }^{39}$ The board also evaluates the functions of the general manager and key employees. Finally, in the annual report, the board reports on the status of the company.

Minimum information must be made available to the board of directors to enable it to perform its responsibilities. The Companies Law of 1997 does not list in detail the minimum information needed. This information should include financial information such as budgets and quarterly reports, information on personnel matters, such as recruitment, resignations, removal and remuneration of key executives, information on

\footnotetext{
35 See Companies Law No. 22 of 1997, Official Gazette No. 4202 (May 15, 1997), supra note 12, art. 146.a.

${ }^{36}$ Id. art. 140.

${ }^{37}$ Id. art. 157.a.

${ }^{38}$ See Directive of Jordan Securities Commission on Disclosure, Accounting, and Auditing Standards of Issuing Companies of 2004, supra note 61, art. 6.c (2).

${ }^{39}$ See Companies Law No. 22 of 1997, Official Gazette No. 4202 (May 15, 1997), supra note 12, art. 153.
} 
serious accidents, pollution problems, possible product liability claims of a substantial nature, substantial payments for intellectual property or goodwill, and details of any foreign exchange exposure and steps taken to hedge the risks.

The Companies Law should clearly set forth powers and responsibilities of the board and a comprehensive system delegating power throughout the various levels of management, executive committee, subcommittees of the board and the full board. Moreover, the Companies Law should clarify the division of powers between management and the board. Currently, there is confusion over the respective roles and responsibilities of the board and management.

\section{Remuneration}

The Companies Law sets a ceiling for remuneration. The Companies Law requires that there shall be a "detailed" disclosure of remuneration, salaries or charges of directors. ${ }^{40}$ Board of directors' remuneration may not exceed ten percent of the company's net annual profit, after deducting legal and optional reserves, up to a maximum of Jordanian Dinar 5,000 (equivalent of US \$7,055). ${ }^{41}$ Thus, remuneration is fixed by law and cannot be modified in the company's articles of association.

The Companies Law should eliminate the cap on remuneration and benefits of board members, but requires remuneration and benefits of board members be approved by the shareholders at the general meeting and prohibits any other payments. ${ }^{42}$ The Companies Law should be amended so as to require a company to develop a transparent and credible policy for determination of remuneration of directors and key executives. How much is

\footnotetext{
${ }^{40} I d$. art. 143.

${ }^{41} I d$. art. 162.

${ }^{42}$ See Charles M. Elson, Director Compensation and the Management-Captured Board - The History of a Symptom and a Cure, 50 SMU L. Rev. 127 (1996).
} 
the board is paid may be unimportant, but how it is paid is more important. Performancerelated elements should form a significant portion of the total remuneration package of the chief executive officer, executive directors and key executives. ${ }^{43}$ If remuneration is performance-based, the company must disclose how the performance is measured and the method of calculation.

The company required by law to disclose information on the compensation of board members and key executives. The report containing compensation and benefits of company directors, list of directors, and duration of board membership must be placed at the company headquarters for inspection three days prior to the general assembly meeting. ${ }^{44}$ However, in practice, companies in Jordan disclose the aggregate compensation for members of the board of directors. Aggregate figures are far less revealing. With segmented figures, it is much easier for a shareholder to detect each of director's compensation as there is a breakdown of compensation into separate lines.

There are several disclosure gaps in the Companies Law of 1997. For example, the Companies Law of 1997 does not require disclosing the employment history of individual board members and key executives. There is no requirement to disclose key issues relevant to employees and stakeholders that may materially affect the performance of the company such as management/employee relations and relations with creditors, suppliers and local communities.

\footnotetext{
${ }^{43}$ Share price-based compensation can form another way to determine remuneration. Share price-based remuneration is an affirmative way to better align the interests of management with those of shareholders. See generally Mark J. Loewenstein, The Conundrum of Executive Compensation, 35 Wake Forest L. Rev. 1 (2000). See also Randall S. Thomas, Explaining the International CEO Pay Gap: Board Capture or Market Driven? 57 Vand. L. Rev. 1171 (2004).

${ }^{44} I d$. art. 143 .
} 


\section{E. Liability, Defenses, and Enforcement}

The Companies Law sets forth directors' liability. The directors and officers must compensate the company, its shareholders, and third parties for any losses caused to them by any breach or failure to comply with the provisions of the law or by any fraud or negligence in the performance of their duties. ${ }^{45}$ If more than one director is liable, each director may be held jointly or severally liable for damages. ${ }^{46}$ The Companies Law prohibits a director or officer from improperly using information obtained because of his position to gain an advantage for himself or another person. ${ }^{47}$ Directors are liable for the damages caused by any fraud or negligence in the performance of their duties. ${ }^{48}$

In the event the company enters into the insolvency process, and if the receiver or liquidator forms the opinion that a director has, among other acts, breached any duty owed to the company, then a motion may be made to the court to require the director to make any contributions to the company's assets that the court thinks proper in the circumstances. ${ }^{49}$ Penalties such as a caution or warning are not available. However, criminal penalties are provided for breach. A director may be held criminally liable and subject to a fine of Jordanian Dinar 1000 to Jordanian Dinar 10000 (\$ 26 to $\$ 13,000)$ and one to three years in jail. ${ }^{50}$

\footnotetext{
${ }^{45}$ See Companies Law No. 22 of 1997, Official Gazette No. 4202 (May 15, 1997), supra note 12, art. 157.a.

${ }^{46} I d$. art. 157.b.

${ }^{47} \mathrm{Id}$. art. 158.

${ }^{48} I d$. art. 159 .

${ }^{49} I d$. art. 257.b.

${ }^{50} I d$. art. 278.
} 
The Companies Law contains an interesting provision where the general assembly can discharge the board from liability. ${ }^{51}$ The Companies Law should not permit the general assembly to discharge the board from this liability because once the board is liable then it is liable, unless defenses are raised against liability.

The Companies Law has not yet elaborated on the defenses available for directors against liability. The Companies Law should provide more guidance and protection to directors. For example, a director may use as a defense against any claim made evidence that he took all "reasonable" steps in the circumstances. The business-judgment rule could also be introduced to protect board from being held liable for good faith business decisions. ${ }^{52}$ The business-judgment rule shields directors from liability for harmful company transactions if transactions were made in good faith and with due care.

Although the Companies Law institutes many provisions on liability, it is not evident from the text of the law how and to what extent the government plans to enforce the liability provisions. In Jordan, lawsuits against directors are rare. Jordan must show that it will prosecute board members in egregious cases.

\section{Conclusions}

Issues of corporate governance are now found on the agenda in Jordan and changes may be in the offing. Indeed, the very term "corporate governance" has entered the Jordanian corporate lexicon. Corporate governance is also frequently the subject of articles in the popular press in Jordan.

\footnotetext{
${ }^{51} I d$. art. 161.

${ }^{52}$ The business-judgment rule is a presumption that in making business decisions not involving direct selfinterest or self-dealing, directors act on an informed basis, in good faith, and in the honest belief that their actions are in the company's best interest. See Stephen M. Bainbridge, The Business Judgment Rule as Abstention Doctrine, 57 Vand. L. Rev. 83, 90-92 (2004).
} 
Although the Companies Law of 1997 incorporates important measures, there are weaknesses in the corporate governance system in areas such as independent directors and compensation. Jordan should implement a model corporate governance system for its capital market. The model corporate governance system can be drawn from best practices from around the world but adapted to the local Jordanian market. In the alternative, Jordan could enact Code of Corporate Governance that pulls many existing corporate governance standards together in one place.

The Companies Law should omit the requirement that substantial shareholders are entitled to seats on the board of directors. The likely result of this requirement is boards of directors manned by unqualified individuals and the inability of a company to achieve an independent board. In addition, Jordan law must detail duties, responsibilities, and functions of board of directors. A training program for board members must be implemented to give an understanding of their roles and duties. As corporate governance standards are improved and directors are held to higher standards, it is important that the Companies Law incorporates a business judgment rule and provides guidance concerning when reliance on information and advice would be considered to be reasonable.

There are many agencies responsible directly or indirectly for the regulation of corporate governance in Jordan. The Companies Law is within the domain of the Ministry of Industry and Trade and Supply while the Securities Law is within the domain of the Jordanian Ministry of Finance. Amman Stock Exchange requires that the companies whose stock is traded on the exchange comply with certain listing requirements, many of which directly address issues of corporate governance. The accounting rulemaking bodies in Jordan also focus on implementing corporate 
governance standards. Bureaucratic turf issues like these may complicate corporate governance reform efforts in Jordan.

Jordan should seek to promote a culture of compliance, transparency and accountability without restraining business initiative. Jordan must also have the will and the proper means to enforce existing laws and regulations, otherwise there is little reason to adopt more, even arguably better, corporate governance regulations. Jordan must demonstrate that it will prosecute board members in egregious cases. Moreover, Jordanian companies need to know that effective corporate governance is an important element of a successful business and can be an invaluable asset for companies seeking external financing. There must be change in mindset. 


\section{List of References}

Al-Basheer, M. The Non-Seriousness of the Regulatory Authorities Prevented Stopping Corruption and Failure of Companies, Al-Rai Newspaper (Apr. 21, 2001).

Andre, Jr., Thomas J. Some Reflections on German Corporate Governance: A Glimpse at German Supervisory Boards, 70 Tul. L. Rev. 1819 (1996).

Austin, R.P. What is Corporate Governance? Precepts and Legal Principles, 3 NZ L. Rev. 335 (2005).

Bainbridge, Stephen M. and M. Todd Henderson. Boards-R-Us: Reconceptualizing Corporate Boards, 66 Stan. L. Rev. 1051 (2014).

Brown, J. Robert. The Demythification of the Board of Directors, 52 Am. Bus. L.J. 131 (2015).

Carney, William J. The Costs of being Public after the Sarbanes-Oxley: The Irony of "Going Private", 55 Emory L.J. 141 (2006).

Companies Law No. 22 of 1997, Official Gazette No. 4202 (May 15, 1997), as amended by Provisional Companies Law No. 40 of 2002, Official Gazette No. 4533 (Feb. 17, 2002).

Directive of Jordan Securities Commission on Disclosure, Accounting, and Auditing Standards of Issuing Companies of 2004.

Elson, Charles M. Director Compensation and the Management-Captured Board - The History of a Symptom and a Cure, 50 SMU L. Rev. 127 (1996).

Governing the Modern Corporation, The Economist, May 5, 2001, at S30.

Grzebielski, Ray J. Friends, Family, Fiduciaries: Personal Relationships as a basis for Insider Trading Violations, 51 Cath. U.L. Rev. 467 (2002).

Held, David \& Anthony McGrew. Globalization, Oxford Companion to Politics of the World (Joel Krieger ed., 2001).

Koraytem, Thabet. The Islamic Nature of the Saudi Regulations for Companies, 15.1 Arab L. Quarterly 63 (2000).

Lin, Laura. The Effectiveness of Outside Directors as a Corporate Governance Mechanism: Theories and Evidence,, 90 Nw. U.L. Rev. 898 (2017).

Licht, Amir N. Cross-Listing and Corporate Governance: Bonding or Avoiding? 4 Chi. J. Int'1 L. 141 (2003). 
Loewenstein, Mark J. The Conundrum of Executive Compensation, 35 Wake Forest L. Rev. 1 (2000).

Mickleth, John \& Adrian Wooldridge. The Company: A Short History of a Revolutionary Idea (2003).

Porta, Rafael La. Corporate Ownership around the World, 54 J. Fin. 471 (1999).

Report of the Committee on the Financial Aspects of Corporate Governance (Dec. 1, 1992).

Seligman, Joel. A Modest Revolution in Corporate Governance, 80 Notre Dame L. Rev. 1159 (2005).

Solomon, Jill \& Aris Solomon. Corporate Governance and Accountability 173 (West Sussex, England: John Wiley \& Sons Ltd 2005)

Thomas, Randall S. Explaining the International CEO Pay Gap: Board Capture or Market Driven? 57 Vand. L. Rev. 1171 (2004).

The Fall of a Kingmaker, The Economist (July 19, 2003).

The Jordanian Civil Code of Moslem Jurisprudence (Hisham R. Hashem trans., 1990). 